\title{
APPLYING THE MULTIDIMENSIONAL ETHICS SCALE IN C2C E-COMMERCE
}

\author{
Kiku Jones, Quinnipiac University, kiku.jones@quinnipiac.edu \\ Lori N. K. Leonard, The University of Tulsa, lori-leonard@utulsa.edu
}

\begin{abstract}
This study contributes to the research of Consumer-to-Consumer $(C 2 C)$ e-commerce seller behavior. Much research has been done in the Business-to-Business e-commerce area (Lima-Filho et al., 2012). However, C2C e-commerce is still an area in need of exploration. The purpose of this study is to measure individual's perceptions regarding various ethical situations involving $\mathrm{C} 2 \mathrm{C}$ e-commerce to determine factors which may influence behavioral intention. Undergraduate students from two US universities evaluated behavioral scenarios to determine if they believe the behavior to be ethical and to examine potential predictors of this determination. The scenarios involved C2C ecommerce decisions on the part of the seller. The participants were given items to examine the influence of moral equity, relativism, egoism, utilitarianism, and contractualism on individual intention in a C2C e-commerce setting. We found full support for moral equity and egoism. Partial support was found for relativism and contractualism. However, no support was found for utilitarianism. C2C e-commerce buyers can use the findings to help during transactions with sellers. Researchers can use the findings as a catalyst for future research in the $\mathrm{C} 2 \mathrm{C}$ e-commerce ethics area. Educators can utilize the scenarios as a focus for ethical discussions in class.
\end{abstract}

Keywords: C2C E-Commerce, Ethics, Multidimensional Ethics Scale, individual intention

\section{INTRODUCTION}

Consumer-to-consumer (C2C) electronic commerce (e-commerce) has revolutionized how people buy and sell. It allows anyone at any time to conduct a transaction with another individual. This form of e-commerce can be found in many venues, such as online auctions, third party listings, web forums, and chat rooms, as well as any place online that allows individuals to make exchanges with one another. These transactions involve both buyers and sellers, and are a unique situation when discussing e-commerce since both parties are consumers (Jones \& Leonard, 2007). Because $\mathrm{C} 2 \mathrm{C}$ e-commerce has opened a new realm of interactions between consumers, there is increased concern regarding how individuals behave in these transactions. Depending on the perspective (buyer or seller), the ethical liability one assumes may be different.

Much research has been devoted to understanding trust in e-commerce in general (Aljifri, Pons, \& Collins, 2003; McKnight, Choudhury, \& Kacmar, 2002) and more specifically in C2C e-commerce (Jones \& Leonard, 2008, 2014; Leonard, 2012; Leonard \& Jones, 2009). However, studies have not addressed how an individual's ethical behavioral intention is influenced during the $\mathrm{C} 2 \mathrm{C}$ e-commerce interactions. This study seeks to address this issue. Using the multidimensional ethics scales (MES), this study will measure an individual's perceptions regarding various ethical situations involving $\mathrm{C} 2 \mathrm{C}$ e-commerce on the part of the seller. The findings will be used to indicate what factors influence an individual's behavioral intention when he/she is involved in a $\mathrm{C} 2 \mathrm{C}$ e-commerce transaction. Reasoning as to how consumers can use these findings in their future $\mathrm{C} 2 \mathrm{C}$ interactions will be provided. The next section will discuss the MES, introduce the research model, and state hypotheses.

\section{MULTIDIMENSIONAL ETHICS SCALE}

The multidimensional ethics scale (MES) is used to provide reasoning as to why an individual might behave a particular way (Reidenbach \& Robin, 1988, 1990; Reidenbach, Robin, \& Dawson, 1991), and assumes that multiple justifications are used when an individual makes an ethical judgment (Clark \& Dawson, 1996). MES offers this reasoning through the use of five theories - moral equity, relativism, egoism, utilitarianism, and contractualism. The composite MES consists of a 12-item instrument that spans across all five theories. Each of the five theories is proposed to influence individual intention, peer intention, and ethical awareness (i.e. three dependent variables). 


\section{Issues in Information Systems \\ Volume 17, Issue I, pp. 26-36, 2016}

Individual intention is one's behavioral intention, which is an individual's intention to perform or not perform an act (Fishbein \& Ajzen, 1975). It is used to measure an individual's intention to behave ethically or unethically. Peer intention is an individual's assessment as to how others his/her age would act in a given situation. Finally, ethical awareness is an individual's assessment of a person's actions in a situation as being ethical or unethical. Figure 1 depicts the research model. This study focuses specifically on individual intention to behave ethically in the $\mathrm{C} 2 \mathrm{C} \mathrm{e}-$ commerce environment and therefore only measures one dependent variable (instead of all three indicated in the MES instrument). Individual intention, or behavioral intention, indicates the effort one is willing to put in in order to perform a behavior, and it is, therefore, an accurate predictor of actual behavior (Ajzen, 1991). Each of the five theories is discussed below in relation to individual intention.

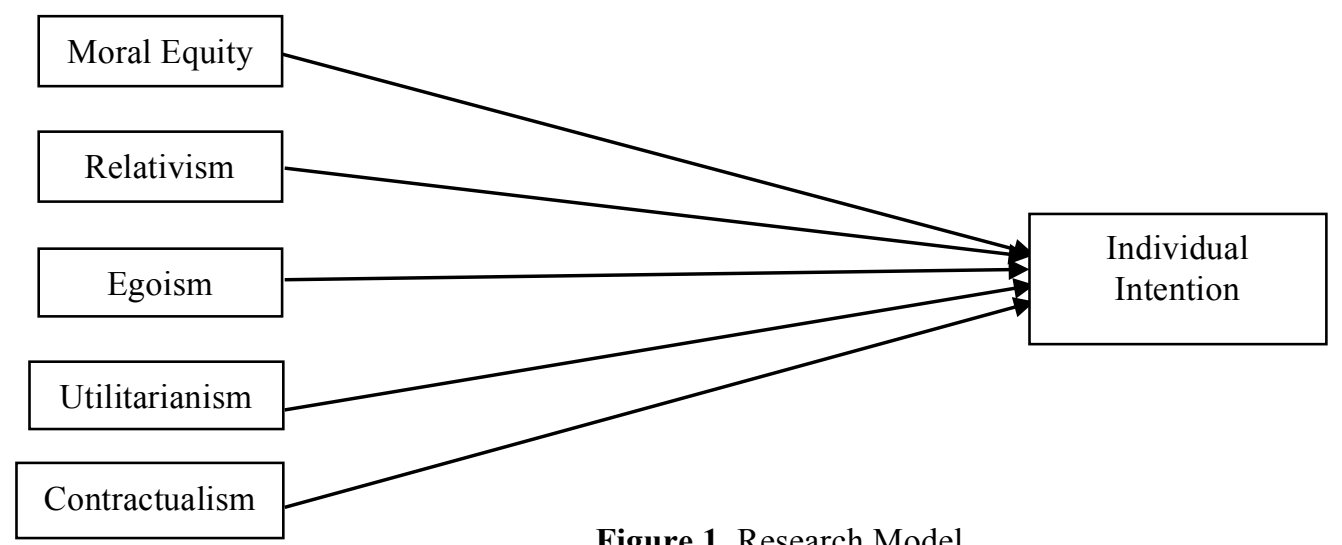

Figure 1. Research Model

\section{Moral Equity}

Moral equity deals with "inherent fairness, justice, goodness and rightness" (Reidenbach \& Robin, 1990, pp. 645646). It also deals with family acceptance. Therefore, moral equity begins in the home with early childhood lessons regarding fairness, goodness, and right and wrong. Moral equity has been studied in fictional situations regarding retail, sales, and automobile repair (Nguyen \& Biderman, 2008). Surveying undergraduate business students, moral equity was found to be related to behavioral intention (Nguyen \& Biderman, 2008). One study conducted in 2015, which also utilized the MES, found that moral equity was one of the strongest influences in determining a student's ethical awareness in academic integrity scenarios utilizing IT (Manly, Leonard, \& Riemenschneider, 2015). In the current study regarding $\mathrm{C} 2 \mathrm{C}$ e-commerce, one would expect that an individual's inherent beliefs regarding right and wrong and goodness and fairness would impact his/her individual intention to behave ethically in the $\mathrm{C} 2 \mathrm{C}$ ecommerce transaction. Therefore, we propose the following hypothesis:

H1: Moral equity will influence one's individual intention to behave ethically in a $\mathrm{C} 2 \mathrm{C}$ e-commerce situation.

\section{Relativism}

Relativism is concerned with the "guidelines, requirements, and parameters inherent in the social/cultural system" (Reidenbach \& Robin, 1990, p. 646). This theory suggests that society and culture play a part in determining an individual's ethical beliefs. Additionally, relativism implies that not one, universal rule exists that governs everyone and everything (Reidenbach et al., 1991). Since societal and cultural understanding come later in life, this theory does not apply to the early childhood stage of development. Manly et al. (Manly et al., 2015) utilized the MES to determine business students' ethical awareness in various academic integrity scenarios utilizing IT. They found that along with moral equity, relativism was one of the strongest influences. In $\mathrm{C} 2 \mathrm{C}$ e-commerce, one would expect that culture and society awareness would play a part in behavioral intention of the individual. Therefore, we propose the following hypothesis:

H2: Relativism will influence one's individual intention to behave ethically in a $\mathrm{C} 2 \mathrm{C}$ e-commerce situation. 


\section{Issues in Information Systems}

Volume 17, Issue I, pp. 26-36, 2016

\section{Egoism}

Egoism is regarding a person's self-promotion and personal gratification (Nguyen \& Biderman, 2008). The theory suggests that "it is possible for an individual to help others, help formulate and follow the rules of society, and even give gifts if that person feels that those actions are in his or her own best interests" (Reidenbach et al., 1991, p. 91). Since $\mathrm{C} 2 \mathrm{C}$ e-commerce transactions impact an individual personally, one would expect that a person's interest in personal gratification to influence his/her behavioral intention. Therefore, we propose the following hypothesis:

H3: Egoism will influence one's individual intention to behave ethically in a $\mathrm{C} 2 \mathrm{C}$ e-commerce situation.

\section{Utilitarianism}

Utilitarianism takes a cost/benefit analysis to determine what the greatest good is for the greatest number of people (Nguyen \& Biderman, 2008). This theory implies that an individual should behave as to create the most good possible as to counter evil that exists in society. In $\mathrm{C} 2 \mathrm{C}$ e-commerce, this would imply that an individual would conduct a transaction looking out for others involved in the transaction. Therefore, we propose the following hypothesis:

H4: Utilitarianism will influence one's individual intention to behave ethically in a $\mathrm{C} 2 \mathrm{C}$ e-commerce situation.

\section{Contractualism}

Contractualism deals with "the idea of a 'social contract' that exists between business and society" (Reidenbach \& Robin, 1990, p. 646). This contract is not written but rather an implied responsibility. In C2C e-commerce there is obviously the obligation of payment made and product received. However, there are additional responsibilities such as playing fair and telling the truth (Reidenbach \& Robin, 1990). This theory also covers unspoken promises and unwritten contracts. Therefore, we propose the following hypothesis:

H5: Contractualism will influence one's individual intention to behave ethically in a $\mathrm{C} 2 \mathrm{C}$ e-commerce situation.

\section{METHOD AND SAMPLE}

Multiple scenarios were developed using the authors' knowledge of $\mathrm{C} 2 \mathrm{C}$ e-commerce. After several iterations, the scenarios and instrument were given to $\mathrm{C} 2 \mathrm{C}$ e-commerce users for feedback. Five users provided feedback that was used to make alterations to the scenarios in order to provide a more realistic situation. The instrument was also refined to help in clarification of items based on user feedback.

Undergraduate students in a Southwestern U.S. university and a Northeastern U.S. university were used as subjects for this study. They were selected based on their enrollment in an MIS/CIS course. Drennan, Mort, \& Previte (2006) indicated the majority of online users are university students. Since these users are the most connected, experienced, and frequent users of the Internet, they are a good representative sample to be used in this study.

Respondents were given an instrument that used the MES (constructs were measured using the items in tables 3-7; individual intention was measured using a single item - "The probability that I would undertake the same action is:" - responses on 7-point scale from high to low) applied to five different $\mathrm{C} 2 \mathrm{C}$ e-commerce scenarios shown in Table 1. Students were asked to apply the MES to each of the scenarios. Student participation was both anonymous and voluntary. Ninety-six responses from students in one university and 206 from the other university were collected. Table 2 provides detailed demographic information from the total sample. Ninety-eight percent of the respondents were between the ages of 17 and 24 . The majority (59\%) of respondents were male. Seventy-four percent of the respondents were white. Fifty-seven percent of the respondents were Freshmen or Sophomores and 33\% were classified as Juniors. 


\section{Issues in Information Systems}

Volume 17, Issue I, pp. 26-36, 2016

\section{DATA ANALYSIS AND RESULTS}

To test for common method variance, Harman's single-factor test was used (Harman, 1967). This test states that if all variables load onto one factor accounting for all of the variance or a factor accounts for the majority of the variance, then the test assumes there is a high level of common method variance present. All variables were entered together and exploratory factor analysis (EFA) was used. Ten factors were found with Eigenvalues greater than 1.0. The variance explained ranged from $1 \%$ to $23 \%$ of the total. These results provide evidence that common method variance is not a concern.

Construct validity and reliability were tested on the multi-item constructs of the model. Factors were extracted using principle component analysis (PCA) with Varimax rotation. The factors with Eigenvalues greater than 1.0 were retained. A .50 cutoff was used to determine high item correlations. These were done for each scenario individually. All Moral Equity items loaded on one factor within each scenario. Cronbach's alpha for the scenarios ranged from .88 to .95 which exceeds the recommended Cronbach's alpha threshold of .50 (Nunnally, 1967). The percent variation explained ranged from $73.95 \%$ to $86.20 \%$. Table 3 provides the results for the factor analysis for the Moral Equity construct per scenario. A Moral Equity variable was calculated for each subject per scenario as the average of the items.

Table 1. C2C E-Commerce Scenarios

\begin{tabular}{|c|c|}
\hline ID & Scenario Text \\
\hline S1 & $\begin{array}{l}\text { Susan is trying to sell one of her old tablets on EBay. She has had no bids for the tablet and the } \\
\text { sale is getting ready to expire in an hour. She receives a message from a potential customer asking } \\
\text { for more pictures of the tablet. The customer believes this is the exact tablet he is looking for and } \\
\text { will likely buy it after receiving a few more pictures. Susan is away from home and would not } \\
\text { return in time to take and send more pictures. However, she has pictures on her phone from } \\
\text { another tablet that she sold last month. It is the same model as the one she is selling now. The two } \\
\text { tablets are in the same condition, with an exception of few scratches on the current one. Susan } \\
\text { doesn't feel that the scratches are so bad that the customer wouldn't still want it, but doesn't really } \\
\text { want to bring attention to them. She decides to send the pictures of the other tablet without letting } \\
\text { the customer know that the pictures are not of the tablet he will be buying. }\end{array}$ \\
\hline S2 & $\begin{array}{l}\text { Jennie's university had a website that allowed students to buy and sell their used textbooks to } \\
\text { each other. Jennie always had great success selling her books because she kept them in great } \\
\text { condition. The website had a feedback mechanism that allowed both buyers and sellers to leave } \\
\text { feedback for each other. Jennie always had great ratings until last semester. She sold a book to } \\
\text { Grace and everything about the transaction went very well. What Jennie didn't know is that Grace } \\
\text { used to date her boyfriend, Sam. When she went to pick up the book, Grace saw a picture of } \\
\text { Jennie and Sam. She was so angry that she posted feedback for Jennie that said no one should buy } \\
\text { from Jennie because the books she had were falling apart. When Jennie saw this, she also posted } \\
\text { terrible feedback for Grace stating that the check she wrote her bounced. }\end{array}$ \\
\hline S3 & $\begin{array}{l}\text { Victoria's friend, Max, is having surgery next week. Max has a lot of listings on EBay and asked } \\
\text { Victoria if she would check on them for him since he would be unable to do anything over the } \\
\text { next four weeks while he was recovering. Max gave Victoria his username and password for his } \\
\text { account. Victoria found herself in need of some quick money and decided to sell some of her } \\
\text { stuff. She realized that Max had a much higher rating than she did and people seemed to always } \\
\text { buy his items as soon as they were listed. While her items, on the other hand, always seemed to } \\
\text { take a long time even if she was selling the same types of items as Max. Since Max wouldn't be } \\
\text { accessing his account for another few weeks, she decided to use his account rather than her own } \\
\text { to sell her items. }\end{array}$ \\
\hline S4 & $\begin{array}{l}\text { Sam and Ginger are both trying to make extra cash by selling items online. They decided to use a } \\
\mathrm{C} 2 \mathrm{C} \text { e-commerce marketplace to sell their items. They discovered that people seemed to buy } \\
\text { items mainly from established sellers with a high amount of positive feedback. They knew it } \\
\text { would take a long time for each of them to build up to these other sellers. So they decided that } \\
\text { they would sign on each week and give each other positive feedback until they reached a good }\end{array}$ \\
\hline
\end{tabular}




\begin{tabular}{|c|l|}
\hline S5 & standing. \\
& $\begin{array}{l}\text { Sally decided to sell her antique figurines. It took her quite a while, but she posted them online } \\
\text { and slowly each one was sold. Sally made sure she posted close-ups of her figurines since most } \\
\text { people were very interested in the condition of the items. When she shipped the items, she was } \\
\text { very careful to wrap each figurine in many layers of packing material to keep them safe. As she } \\
\text { was wrapping up the last sold figurine, she dropped it. Luckily, it landed on the carpet and didn't } \\
\text { break. However, she noticed that there was a tiny chip on the bottom corner of the paint. She } \\
\text { looked back at the pictures she posted and saw that she never posted a picture with that part } \\
\text { showing. Even though she described the item as not having any flaws, she decided to pack it up } \\
\text { and send it anyway without letting the customer know what happened. }\end{array}$ \\
\hline
\end{tabular}

Table 2. Demographic Information

\begin{tabular}{|c|c|c|}
\hline \multicolumn{2}{|c|}{ Demographic Variable } & MES Survey \\
\hline Age & 17 to 24 & $98 \%$ \\
\hline & 25 and older & $2 \%$ \\
\hline Gender & Male & $59 \%$ \\
\hline & Female & $41 \%$ \\
\hline Major & Accounting & $14 \%$ \\
\hline & Economics & $1 \%$ \\
\hline & Energy Management & $4 \%$ \\
\hline & Finance & $12 \%$ \\
\hline & Management & $9 \%$ \\
\hline & Marketing & $14 \%$ \\
\hline & CIS/MIS & $17 \%$ \\
\hline & Entrepreneurship & $4 \%$ \\
\hline & Other/Unknown & $25 \%$ \\
\hline Race & White & $74 \%$ \\
\hline & African American & $6 \%$ \\
\hline & Asian & $12 \%$ \\
\hline & Multiple Races & $7 \%$ \\
\hline & Other/Unknown & $1 \%$ \\
\hline Classification & Freshmen & $50 \%$ \\
\hline & Sophomore & $7 \%$ \\
\hline & Junior & $33 \%$ \\
\hline & Senior & $9 \%$ \\
\hline & Other/Unknown & $1 \%$ \\
\hline
\end{tabular}

Table 3. Moral Equity Construct Factor Analysis

\begin{tabular}{|lccccc|}
\hline & \multicolumn{5}{c|}{ Scenario } \\
Moral Equity & S1 & S2 & S3 & S4 & S5 \\
Unjust/Just & 0.85 & 0.87 & 0.92 & 0.91 & 0.93 \\
Unfair/Fair & 0.90 & 0.90 & 0.93 & 0.94 & 0.92 \\
Not Morally right/Morally right & 0.85 & 0.91 & 0.94 & 0.92 & 0.90 \\
Acceptable/Not Acceptable to my Family & 0.84 & 0.87 & 0.92 & 0.89 & 0.89 \\
Cronbach's alpha & 0.88 & 0.91 & 0.95 & 0.94 & 0.93 \\
Eigenvalue & 2.96 & 3.13 & 3.45 & 3.35 & 3.30 \\
Variance Explained & $73.95 \%$ & $78.28 \%$ & $86.20 \%$ & $83.85 \%$ & $82.48 \%$ \\
\hline
\end{tabular}

All Relativism items loaded on one factor within each scenario. Cronbach's alpha for the scenarios ranged from .67 to .88 which exceeds the recommended Cronbach's alpha threshold of .50 (Nunnally, 1967). The percent variation explained ranged from $77.73 \%$ to $89.22 \%$. Table 4 provides the results for the factor analysis for the Relativism 
construct per scenario. A Relativism variable was calculated for each subject per scenario as the average of the items.

Table 4. Relativism Construct Factor Analysis

\begin{tabular}{|lccccc|} 
Relativism & S1 & S2 & S3 & S4 & S5 \\
Culturally Unacceptable/Culturally Acceptable & 0.90 & 0.88 & 0.95 & 0.90 & 0.93 \\
Traditionally Unacceptable/Traditionally Acceptable & 0.90 & 0.88 & 0.95 & 0.90 & 0.93 \\
Cronbach's & 0.75 & 0.67 & 0.88 & 0.77 & 0.85 \\
Eigenvalue & 1.61 & 1.56 & 1.78 & 1.63 & 1.74 \\
Variance Explained & $80.26 \%$ & $77.73 \%$ & $89.22 \%$ & $81.23 \%$ & $87.11 \%$ \\
\hline
\end{tabular}

All Egoism items loaded on one factor within each scenario. Cronbach's alpha for the scenarios ranged from .82 to .93 which exceeds the recommended Cronbach's alpha threshold of .50 (Nunnally, 1967). The percent variation explained ranged from $85.81 \%$ to $93.54 \%$. Table 5 provides the results for the factor analysis for the Egoism construct per scenario. An Egoism variable was calculated for each subject per scenario as the average of the items.

Table 5. Egoism Construct Factor Analysis

\begin{tabular}{|lccccc|}
\hline Egoism & $\mathbf{S 1}$ & $\mathbf{S 2}$ & $\mathbf{S 3}$ & $\mathbf{S 4}$ & $\mathbf{S 5}$ \\
Not Self-promoting for me/Self-promoting for me & 0.93 & 0.95 & 0.97 & 0.93 & 0.95 \\
Not personally satisfying for me/Personally satisfying & & & & & \\
for me & 0.93 & 0.95 & 0.97 & 0.93 & 0.95 \\
Cronbach's & 0.85 & 0.88 & 0.93 & 0.82 & 0.89 \\
Eigenvalue & 1.74 & 1.8 & 1.87 & 1.72 & 1.81 \\
Variance Explained & $87.05 \%$ & $89.79 \%$ & $93.54 \%$ & $85.81 \%$ & $90.27 \%$ \\
\hline
\end{tabular}

All Utilitarianism items loaded on one factor within each scenario. Cronbach's alpha for the scenarios ranged from .71 to .86 which exceeds the recommended Cronbach's alpha threshold of .50 (Nunnally, 1967). The percent variation explained ranged from $77.78 \%$ to $87.48 \%$. Table 6 provides the results for the factor analysis for the Utilitarianism construct per scenario. A Utilitarianism variable was calculated for each subject per scenario as the average of the items.

Table 6. Utilitarianism Construct Factor Analysis

\begin{tabular}{lccccc|}
\hline Utilitarianism & S1 & S2 & S3 & S4 & S5 \\
Produces the least utility/Produces the greatest utility & 0.88 & 0.91 & 0.94 & 0.91 & 0.91 \\
$\begin{array}{l}\text { Minimizes the benefits while maximizes } \\
\text { harm/Maximizes benefits while minimizes harm }\end{array}$ & 0.88 & 0.91 & 0.94 & 0.91 & 0.91 \\
Cronbach's & 0.71 & 0.78 & 0.86 & 0.80 & 0.79 \\
Eigenvalue & 1.56 & 1.64 & 1.75 & 1.66 & 1.65 \\
Variance Explained & $77.78 \%$ & $82.07 \%$ & $87.48 \%$ & $83.18 \%$ & $82.69 \%$ \\
\hline
\end{tabular}

All Contractualism items loaded on one factor within each scenario. Cronbach's alpha for the scenarios ranged from .82 to .97 which exceeds the recommended Cronbach's alpha threshold of .50 (Nunnally, 1967). The percent variation explained ranged from $84.86 \%$ to $96.94 \%$. Table 7 provides the results for the factor analysis for the Contractualism construct per scenario. A Contractualism variable was calculated for each subject per scenario as the average of the items.

Table 7. Contractualism Construct Factor Analysis

\begin{tabular}{|lccccc|}
\hline $\begin{array}{l}\text { Contractualism } \\
\text { Violates an unwritten contract/Does not violate an } \\
\text { unwritten contract }\end{array}$ & S1 & S2 & S3 & S4 & S5 \\
$\begin{array}{l}\text { Violates an unspoken promise/Does not violate an } \\
\text { unspoken promise }\end{array}$ & 0.92 & 0.98 & 0.99 & 0.98 & 0.98 \\
\hline
\end{tabular}




\begin{tabular}{|lccccc|}
\hline Cronbach's & 0.82 & 0.96 & 0.97 & 0.96 & 0.96 \\
Eigenvalue & 1.70 & 1.93 & 1.94 & 1.92 & 1.92 \\
Variance Explained & $84.86 \%$ & $96.42 \%$ & $96.94 \%$ & $96.02 \%$ & $95.86 \%$ \\
\hline
\end{tabular}

\section{Model Testing}

Regression analysis was performed to test the relationships between the construct variables and individual intention. Tolerance levels were examined for each of the independent variables in the scenario models. All levels were above .1 suggesting there is no problem with multicollinearity in the data.

Table 8 indicates which hypotheses were supported. Table 9 - Table 13 show the results of the regression results on individual intention using the independent constructs by scenario. Support across all scenarios was found for H1 and H3. Partial support was found for H2 and H5. H4 was not supported.

Table 8. Hypotheses Results

\begin{tabular}{|l|l|}
\hline \multicolumn{1}{|c|}{ Hypotheses: Independent Variable } & \multicolumn{1}{c|}{ Result } \\
\hline H1: Moral Equity & Support across all scenarios \\
\hline H2: Relativism & Partial support (Scenario 3) \\
\hline H3: Egoism & Support across all scenarios \\
\hline H4: Utilitarianism & No Support \\
\hline H5: Contractualism & Partial Support (Scenarios 1, 4, and 5) \\
\hline
\end{tabular}

Table 9. Scenario 1 - Wrong Tablet

\begin{tabular}{|c|c|c|c|c|}
\hline \multicolumn{5}{|c|}{ Independent Variable: Individual Intention } \\
\hline $\begin{array}{c}\text { Independent } \\
\text { Variable }\end{array}$ & Standardized Beta & Standard error & $t$ & $p$ \\
\hline Moral Equity & -0.513 & 0.12 & -5.987 & $0.000^{* * *}$ \\
\hline Relativism & 0.08 & 0.09 & 1.142 & 0.255 \\
\hline Egoism & -0.25 & 0.099 & -3.186 & $0.002^{* * *}$ \\
\hline Utilitarianism & -0.07 & 0.085 & -1.016 & 0.311 \\
\hline Contractualism & 0.157 & 0.078 & 2.401 & $0.017^{*}$ \\
\hline
\end{tabular}

Overall model: $\mathrm{p}=.000 ; \mathrm{R} 2=.388 ; * * * \mathrm{p}<0.01,{ }^{* *} \mathrm{p}<0.05 ;{ }^{*} \mathrm{p}<0.10$

Table 10. Scenario 2 - Incorrect Feedback

\begin{tabular}{|c|c|c|c|c|}
\hline \multicolumn{5}{|c|}{ Independent Variable: Individual Intention } \\
\hline $\begin{array}{c}\text { Independent } \\
\text { Variable }\end{array}$ & Standardized Beta & Standard error & $t$ & $p$ \\
\hline Moral Equity & -0.422 & 0.118 & -4.787 & $0.000^{* * *}$ \\
\hline Relativism & 0.028 & 0.08 & 0.41 & 0.682 \\
\hline Egoism & -0.371 & 0.103 & -4.527 & $0.000^{* * *}$ \\
\hline Utilitarianism & 0.054 & 0.105 & 0.721 & 0.472 \\
\hline Contractualism & 0.003 & 0.08 & 0.042 & 0.967 \\
\hline
\end{tabular}

Overall model: $\mathrm{p}=.000 ; \mathrm{R} 2=.471 ;{ }^{* * *} \mathrm{p}<0.01,{ }^{* *} \mathrm{p}<0.05 ;{ }^{*} \mathrm{p}<0.10$

Table 11. Scenario 3 - Imposter Seller

\begin{tabular}{|c|c|c|c|c|}
\hline \multicolumn{5}{|c|}{ Independent Variable: Individual Intention } \\
\hline $\begin{array}{c}\text { Independent } \\
\text { Variable }\end{array}$ & Standardized Beta & Standard error & $t$ & $p$ \\
\hline Moral Equity & -0.324 & 0.13 & -3.175 & $0.002^{* * *}$ \\
\hline Relativism & -0.166 & 0.107 & -1.937 & $0.054^{*}$ \\
\hline
\end{tabular}




\begin{tabular}{|c|c|c|c|c|}
\hline Egoism & -0.354 & 0.109 & -3.769 & $0.000^{* * *}$ \\
\hline Utilitarianism & 0.056 & 0.097 & 0.693 & 0.489 \\
\hline Contractualism & 0.071 & 0.081 & 1.016 & 0.311 \\
\hline
\end{tabular}

Overall model: $\mathrm{p}=.000 ; \mathrm{R} 2=.482 ;{ }^{* * *} \mathrm{p}<0.01,{ }^{* *} \mathrm{p}<0.05 ;{ }^{*} \mathrm{p}<0.10$

Table 12. Scenario 4 - False Positives

\begin{tabular}{|c|c|c|c|c|}
\hline \multicolumn{5}{|c|}{ Independent Variable: Individual Intention } \\
\hline $\begin{array}{c}\text { Independent } \\
\text { Variable }\end{array}$ & Standardized Beta & Standard error & $t$ & $p$ \\
\hline Moral Equity & -0.409 & 0.13 & -4.317 & $0.000^{* * *}$ \\
\hline Relativism & -0.005 & 0.114 & -0.066 & 0.948 \\
\hline Egoism & -0.355 & 0.087 & -4.466 & $0.000^{* * *}$ \\
\hline Utilitarianism & 0.019 & 0.099 & 0.235 & 0.814 \\
\hline Contractualism & 0.144 & 0.095 & 1.889 & $0.060^{*}$ \\
\hline
\end{tabular}

Overall model: $\mathrm{p}=.000 ; \mathrm{R} 2=.349 ; * * * \mathrm{p}<0.01,{ }^{*} \mathrm{p}<0.05 ;{ }^{*} \mathrm{p}<0.10$

Table 13. Scenario 5 - Defective Product

Independent Variable: Individual Intention

\begin{tabular}{|c|c|c|c|c|}
\hline \multicolumn{5}{|c|}{ Independent Variable: Individual Intention } \\
\hline $\begin{array}{c}\text { Independent } \\
\text { Variable }\end{array}$ & Standardized Beta & Standard error & $t$ & $p$ \\
\hline Moral Equity & -0.498 & 0.17 & -4.129 & $0.000^{* * *}$ \\
\hline Relativism & -0.014 & 0.123 & -0.153 & 0.879 \\
\hline Egoism & -0.226 & 0.129 & -2.185 & $0.030^{* *}$ \\
\hline Utilitarianism & -0.071 & 0.118 & -0.787 & 0.432 \\
\hline Contractualism & 0.368 & 0.113 & 4.073 & $0.000^{* * *}$ \\
\hline
\end{tabular}

Overall model: $\mathrm{p}=.000 ; \mathrm{R} 2=.266 ;{ }^{* * *} \mathrm{p}<0.01,{ }^{*} \mathrm{p}<<0.05 ;{ }^{*} \mathrm{p}<0.10$

\section{DISCUSSION}

MES was used in this study to explain individual intention to behave ethically in the $\mathrm{C} 2 \mathrm{C}$ e-commerce setting. The results of this study will help those wishing to transact in this setting to have a better understanding of the ethical judgments made by the $\mathrm{C} 2 \mathrm{C}$ e-commerce sellers. For each of the scenarios, moral equity influences an individual's intention to behave ethically which means that a person having higher morals is less likely to have the intention to behave unethically (H1). This provides additional support for studies previously done in the area of ethics. This finding suggests that a person's inherent beliefs regarding right and wrong and fairness impact his/her individual intention to behave ethically in the $\mathrm{C} 2 \mathrm{C}$ e-commerce environment.

Only partial support was found for relativism (H2). The only scenario that supported relativism was scenario 3 which dealt with a seller impersonating another seller with a higher rating. This indicates that the respondents felt this ethical judgment was not culturally or traditionally acceptable. Perhaps, support was only found for this scenario because this is the only one where a person was being misrepresented. Impersonating another seller appears to be more of an offense. This can be considered good news for buyers in that they can feel fairly confident that they are dealing with the appropriately identified seller.

Egoism (H3) was also found to influence individual intention to behave ethically across all scenarios. This indicates that the participants' personal gratification was important when making ethical judgments. This finding is consistent with previous studies performed in the area of ethics. Buyers can use this to their advantage by framing the transaction in a way that gives the seller personal satisfaction in the $\mathrm{C} 2 \mathrm{C}$ transaction. For example, letting the seller know how much it would help the buyer's situation if he/she could come down on the price, giving the seller a feeling of being the hero. 


\section{Issues in Information Systems \\ Volume 17, Issue I, pp. 26-36, 2016}

Utilitarianism (H4) did not find support in any of the scenarios. Perhaps this is because the consequences for the behavior in the scenarios were not big enough to warrant a feeling of "good vs. evil". If the consequences of the actions were larger in scale to the buyer, a different result may have been seen. With each scenario, the buyer still received the expected product with little if any variation from what the seller posted. There may be a threshold of negative consequences that must be met before utilitarianism has an influence on individual intention.

Contractualism (H5) had partial support. Scenarios 1 (wrong tablet), 4 (false positive) and 5 (defective product) supported it. This indicates that, for these situations, the respondents felt that unspoken and unwritten contracts were broken. In scenarios 1 and 5, the seller provided the product described in the $\mathrm{C} 2 \mathrm{C}$ e-commerce marketplace in exchange for payment. So there was no violation to the written contract. However, in sending pictures of a different tablet, albeit the same model, and sending the defective antique, the "social contract" was broken. The lack of disclosure on the part of the seller played into this. In regards to scenario 4, the $\mathrm{C} 2 \mathrm{C}$ e-commerce community has an unspoken/unwritten expectation when it comes to the buyer feedback. This is the mechanism by which many buyers make the determination of whom they should conduct their business (Hu, Bose, Koh, \& Liu, 2012). This appears to be of importance in determining individual intention to behave ethically. Once again this is good news for buyers in that even when contracts are not explicit, it appears that they are taken into account in regards to a seller's individual intention.

\section{LIMITATIONS AND FUTURE RESEARCH}

Our study utilized university students as survey subjects. Samples for future research should include subjects from older users of $\mathrm{C} 2 \mathrm{C}$ e-commerce. The findings may be influenced by changes of society over time. Expectations from an older group of respondents may reflect the generational changes. McCloskey (2006) found when studying consumers in the age range of 52 to 87 , that they have different influences in the online environment. This age group is indeed participating in the $\mathrm{C} 2 \mathrm{C}$ e-commerce environment. However, they have yet to be studied. A comparison of university students vs. this age group would be quite interesting.

The scenarios used for this study were only a portion of potential situations in regards to ethical judgment in the $\mathrm{C} 2 \mathrm{C}$ e-commerce area. Future research should expand the scenarios to include other situations that are prevalent. In addition, having the scenarios from the buyer's perspective may find differing results. Future researchers should attempt to collect buyer responses and compare the results.

Researchers will want to look at these scenarios and capture data regarding the five independent variables on the other two dependent variables (peer intention and ethical awareness) that were discussed by Shawver and Sennetti (2009). It may be that the variables found to influence individual intention to behave unethically are quite different than what is found to influence the others in a $\mathrm{C} 2 \mathrm{C}$ e-commerce setting.

In addition, educators can utilize these ethical scenarios as discussion points. Material regarding ethics in IT can often be structured around corporate settings. While important to frame ethics in this area, it may be difficult for some students who haven't worked in a corporation to fully grasp the concept. The ethical scenarios presented here are put in settings that are likely familiar to university students (i.e., selling tablets, selling books, selling on Ebay, etc.). These can be used a springboard for more in depth ethical discussions.

\section{CONCLUSION}

This study used the MES to look at the influence of moral equity, relativism, egoism, utilitarianism, and contractualism on individual intention of sellers to behave ethically in the $\mathrm{C} 2 \mathrm{C}$ e-commerce setting. The study found support for moral equity and egoism and partial support for relativism and contractualism. Buyers in the $\mathrm{C} 2 \mathrm{C}$ ecommerce environment can use these findings when dealing with sellers by finding ways to posit transactions which would ultimately benefit them and result in a better ending. Buyers can also take comfort in the findings that moral 
equity influenced individual intention to behave ethically. This is an indication that the seller will behave in an ethical manner that is translated from their understanding of right and wrong.

Researchers can use this study as a springboard into the ethical side of $\mathrm{C} 2 \mathrm{C}$ e-commerce. Studies need to be conducted that include the buyers' ethical decisions that are made during $\mathrm{C} 2 \mathrm{C}$ e-commerce transactions. In addition, comparisons of behavior for an individual as the seller vs. the buyer should be made. Researchers can also take this study further by looking at how these five theories influence peer intention and ethical awareness.

\section{REFERENCES}

Ajzen, I. (1991). The Theory of Planned Behavior. Organizational Behavior and Human Decision Processes, 50(2), 179-211.

Aljifri, H. A., Pons, A., \& Collins, D. (2003). Global e-commerce: a framework for understanding and overcoming the trust barrier. Information Management \& Computer Security, 11(3), 130-138.

Clark, J. W., \& Dawson, L. E. (1996). Personal religiousness and ethical judgments: an empirical analysis. Journal of Business Ethics, 15, 359-372.

Drennan, J., Mort, G. S., \& Previte, J. (2006). Privacy, Risk Perception, and Expert Online Behavior: An Exploratory Study of Household End Users. Journal of Organizational and End User Computing, 18(1), 122.

Fishbein, M., \& Ajzen, I. (1975). Belief, Attitude, Intention and Behavior: An Introduction to Theory and Research. Reading, NJ: Addison-Wesley.

Harman, H. H. (1967). Modern Factor Analysis. Chicago: University of Chicago Press.

Hu, N., Bose, I., Koh, N. S., \& Liu, L. (2012). Manipulation of online reviews: An analysis of ratings, readability, and sentiments. Decision Support Systems, 52(3), 674-684.

Jones, K., \& Leonard, L. N. K. (2007). Consumer-to-Consumer Electronic Commerce: A Distinct Research Stream. Journal of Electronic Commerce in Organizations, 5(4), 39-54.

Jones, K., \& Leonard, L. N. K. (2008). Trust in Consumer-to-Consumer Electronic Commerce. Information \& Management, 45, 88-95.

Jones, K., \& Leonard, L. N. K. (2014). Factors Influencing Buyer's Trust in Consumer-to-Consumer E-Commerce. Journal of Computer Information Systems, 54(4), 71-79.

Leonard, L. N. K. (2012). Attitude Influencers in C2C E-Commerce: Buying and Selling. Journal of Computer Information Systems, 11-17.

Leonard, L. N. K., \& Jones, K. (2009). The Role of Self-Efficacy, Trust, and Experience and the Mediating Effects of Satisfaction in the Choice of C2C E-Commerce among Young Adults. Journal of Electronic Commerce in Organizations, 7(3), 1-20.

Lima-Filho, D. D., Alves, C. D., Quevedo-Silva, F., Moreira, L. B., Garcez, V. R., \& Aratani, W. F. (2012). Profile of the Electronic Commerce Consumer: A Study with Brazilian University Students. Journal of Internet Banking and Commerce, 17(1), 1-16. 


\section{Issues in Information Systems}

Volume 17, Issue I, pp. 26-36, 2016

Manly, T. S., Leonard, L. N., \& Riemenschneider, C. K. (2015). Academic Integrity in the Information Age: Virtues of Respect and Responsibility. Journal of Business Ethics, 127(3), 579-590.

McCloskey, D. W. (2006). The Importance of Ease of Use, Usefulness, and Trust to Online Consumers: An Examination of the Technology Acceptance Model with Older Consumers. Journal of Organizational and End User Computing, 18(3), 47-65.

McKnight, D. H., Choudhury, V., \& Kacmar, C. (2002). Developing and validating trust measures for e-commerce: an integrative topology. Information Systems Research, 13(3), 334-359.

Nguyen, N. T., \& Biderman, M. D. (2008). Studying ethical judgments and behavioral intentions using structural equations: evidence from the multidimensional ethics scale. Journal of Business Ethics, 83, 627-640.

Nunnally, J. C. (1967). Psychometric Theory. New York: McGraw-Hill.

Reidenbach, R. E., \& Robin, D. P. (1988). Some initial steps toward improving the measurement of ethical evaluations of marketing activities. Journal of Business Ethics, 7, 871-879.

Reidenbach, R. E., \& Robin, D. P. (1990). Toward the Development of a Multidimensional Scale for Improving Evaluations of Business Ethics. Journal of Business Ethics, 9(8), 639-653.

Reidenbach, R. E., Robin, D. P., \& Dawson, L. (1991). An application and extension of a multidimensional ethics scale to selected marketing practices and marketing groups. Journal of the Academy of Marketing Science, $19(2), 83-92$.

Shawver, T. J., \& Sennetti, J. T. (2009). Measuring ethical sensitivity and evaluation. Journal of Business Ethics, 88, 663-678. 